\title{
TRANSPORT AND ACCUMULATION OF HEAVY METALS IN UNDISTURBED SOIL COLUMNS
}

\author{
I.V. ERMAKOV ${ }^{1, *}$ \\ S.V. KOPTSIK ${ }^{2}$ \\ G.N. KOPTSIK ${ }^{1}$ \\ S. LOFTS ${ }^{3}$
}

Received: $11 / 04 / 07$

Accepted: 04/05/07

\author{
${ }^{1}$ Soil Science Faculty, Moscow State University, \\ Moscow, 119992, Russia \\ ${ }^{2}$ Physics Faculty, Moscow State University, \\ Moscow, 119992, Russia \\ ${ }^{3} \mathrm{CEH}$, Lancaster Environment Centre, \\ Library Avenue, Bailrigg, Lancaster LA1 4AP, UK
}

*to whom all correspondence should be addressed: e-mail: ierm@mail.ru

\begin{abstract}
The podzolic soils of the Kola Peninsula, Russia, have in localised areas been highly contaminated with copper and nickel from smelting activities. Migration and retention of these metals were investigated in undisturbed soil columns irrigated with simulated background and polluted precipitation in order to study the temporal processes of retention and release within the soil. The mineral layers were strongly acidified by the contaminated precipitation. Forest floor layers demonstrated a high capacity to retain input $\mathrm{Ni}$ and $\mathrm{Cu}$ under all conditions. Mineral layers accumulated some $\mathrm{Cu}$, but released $\mathrm{Ni}$. In general, $\mathrm{Ni}$ leached through the soil faster than $\mathrm{Cu}$. Since metals are strongly retained in the forest floor layer, even after reduction or cessation of inputs there may be a significant long-term risk of their leaching to deeper soil and groundwater. This risk cannot be ameliorated without remediative intervention.
\end{abstract}

KEYWORDS: podzol soil, column experiment, nickel, copper, buffer capacity, dissolved organic carbon, smelter

\section{INTRODUCTION}

The protection and restoration of the environment is nowadays a crucial issue for the Kola Peninsula area of Russia. Terrestrial ecosystems of the Kola Peninsula have for several decades been affected by emissions from the "Severonikel" nickel-copper smelter, one of the world's largest point sources of sulphur dioxide and heavy metals. Industrial dust produced by the smelter contains a large number of elements: $\mathrm{Ag}, \mathrm{Al}, \mathrm{As}, \mathrm{B}, \mathrm{Ba}, \mathrm{Be}, \mathrm{Bi}, \mathrm{Ca}, \mathrm{Cd}, \mathrm{Cl}, \mathrm{Co}, \mathrm{Cr}$, $\mathrm{F}, \mathrm{Fe}, \mathrm{K}, \mathrm{La}, \mathrm{Li}, \mathrm{Mg}, \mathrm{Mn}, \mathrm{Mo}, \mathrm{Na}, \mathrm{P}, \mathrm{Pb}, \mathrm{Sb}, \mathrm{Sc}, \mathrm{Se}, \mathrm{Si}, \mathrm{Sr}$, Th, Ti, Tl, U, V, Y and Zn (Koptsik et al., 1998; Lukina and Nikonov, 1996; Nikonov et al., 2001). Copper and nickel are the main metallic pollutants. Typical for the area podzol soils are sensitive to pollution due to low buffer capacity to acid and heavy metal inputs as a result of coarse sandy texture, low organic matter content, low concentrations of base cations and low $\mathrm{pH}$.

Acid deposition effects have been studied in detail in the Kola region since sulphur emissions have caused regional and transboundary pollution problems (Koptsik and Koptsik, 2001; Lukina and Nikonov, 1996). The heavy metal contamination is much more localized because the particulate matter containing the metals is deposited at relatively short distances from the smelter (up to tens of kilometres); nevertheless, the metal pollution can contribute significantly to adverse effects. Dust is deposited to soil and vegetation surfaces. Metals deposited to soil may transform (solubilise) into more mobile forms capable of migrating into the soil water where they may pose an elevated risk to plants, other soil biota and to groundwater. Despite the obvious ecological risks and the potential need for information to support soil restoration strategies, the accumulation, migration and fate of heavy metals in these soils are not completely understood. 
It is impossible to elaborate effective methods of soil cleaning and remediation without background knowledge of pollutant behaviour. But investigations of heavy metal migration and accumulation in natural conditions are very laborious as it is difficult to control all numerous factors influencing metal behaviour in the field. Laboratory model experiments, by eliminating some confounding factors, can be effective in studying certain features of metal behaviour in soils. Using columns of uncontaminated soil from the same region and applying artificial 'polluted' solutions helps to elucidate the mechanisms of heavy metal accumulation and migration in soil (Camobreco et al., 1996; Mc-Laren et al., 1994). Knowledge of such mechanisms provides selection of maximally effective soil remediation methods.

The aim of our study was to study the major patterns of $\mathrm{Ni}$ and $\mathrm{Cu}$ behaviour in soil columns subject to simulated atmospheric precipitation. Since there are many indications that the forest floor layer can act as a barrier to metal migration (Derome and Lindroos, 1998; Koptsik et al., 1998; Koptsik et al., 2003; Nikonov et al., 2001), we also used uncontaminated forest floor samples affected by the same precipitation types.

\section{MATERIALS AND METHODS}

\subsection{Study soils and sampling}

Podzol soils are thought to be a product of interaction between sandy parent rocks and coniferous forests which are widespread in the boreal environment. In the Kola Peninsula, podzols are usually formed on sorted glacial deposits and unsorted tills with coarse structure and have a shallow profile with total depth of 30-50 cm (Koptsik et al., 1998; Lukina and Nikonov, 1996). Podzols are characterized by the presence of two geochemical barriers: forest floors (organic horizons $\mathrm{O}$ ) and mineral illuvial horizons $\left(\mathrm{B}_{\mathrm{hf}}\right)$. These horizons differ significantly in their properties, including their organic matter content (Table 1). In boreal forests the well-developed forest floor, with high organic matter content, is able to accumulate large amounts of deposited heavy metals. The retentive capacity of the illuvial horizons tends to be lower than that of the forest floor and derives mainly from the presence of clays and mineral oxides of $\mathrm{Al}$ and Fe (III), as well as organic matter.

Table 1. General properties and heavy metal content in background and polluted soils

\begin{tabular}{|c|c|c|c|c|c|c|c|c|c|c|c|}
\hline \multirow{2}{*}{$\begin{array}{l}\text { Hori- } \\
\text { zon }\end{array}$} & Depth & Clay & $\mathrm{Al}_{\mathrm{O}}$ & $\mathrm{Fe}_{0}$ & $\mathrm{C}_{\text {org }}$ & \multirow[b]{2}{*}{$\mathrm{pH}_{\mathrm{H} 20}$} & \multirow[b]{2}{*}{$\mathrm{pH}_{\mathrm{CaCl} 2}$} & $\mathrm{Ni}_{\mathrm{AR}}{ }^{*}$ & $\mathrm{Ni}_{\text {HNO3 }}{ }^{* *}$ & $\mathrm{Cu}_{\mathrm{AR}}{ }^{*}$ & $\mathrm{Cu}_{\mathrm{HNO} 3}{ }^{* *}$ \\
\hline & $\mathrm{cm}$ & $\%$ & $\mathrm{mg} \mathrm{kg}^{-1}$ & $\mathrm{mg} \mathrm{kg}^{-1}$ & $\%$ & & & $\mathrm{mg} \mathrm{kg}$ & $\mathrm{mg} \mathrm{kg}^{-1}$ & ${ }_{1}^{\mathrm{mg} \mathrm{kg}}$ & $\mathrm{mg} \mathrm{kg}^{-1}$ \\
\hline \multicolumn{12}{|c|}{ Background soil, $200 \mathrm{~km}$ from the smelter } \\
\hline $\mathrm{O}$ & $0-7$ & - & 460 & 1200 & 39.8 & 3.9 & 3.4 & 10 & 4.1 & 6.5 & 6.2 \\
\hline$E$ & $7-12$ & 6.0 & 180 & 72 & 0.9 & 4.0 & 3.3 & 0.9 & 0.2 & 0.7 & 0.6 \\
\hline $\mathrm{B}_{\mathrm{hf}}$ & $12-18$ & 11.0 & 15200 & 26600 & 2.1 & 4.5 & 4.1 & 15 & 1.2 & 7.1 & 1.4 \\
\hline $\mathrm{BC}$ & $18-24$ & 3.7 & 8700 & 3000 & 0.8 & 5.1 & 4.7 & 25 & 1.2 & 12.3 & 1.6 \\
\hline C & $24-50$ & 5.1 & 2800 & 650 & 0.3 & 5.1 & 4.6 & 15 & 0.7 & 9.3 & 1.3 \\
\hline \multicolumn{12}{|c|}{ Polluted soil, $7 \mathrm{~km}$ from the smelter } \\
\hline $\mathrm{O}$ & $0-6$ & - & 1400 & 2580 & 35.5 & 4.0 & 3.3 & 2270 & 580 & 1950 & 1540 \\
\hline$E$ & $6-7$ & 4.5 & 480 & 620 & 0.9 & 3.8 & 3.2 & 28 & 8.5 & 25 & 16 \\
\hline$B_{h f}$ & $7-23$ & 5.7 & 21400 & 8100 & 4.3 & 4.6 & 4.3 & 130 & 15 & 150 & 110 \\
\hline$B C$ & 23-29 & 3.8 & 21700 & 4000 & 1.3 & 5.5 & 5.1 & 202 & 26 & 39 & 4.8 \\
\hline C & $29-60$ & 4.1 & 7500 & 580 & 0.6 & 5.6 & 5.0 & 83 & 6.6 & 42 & 3.3 \\
\hline
\end{tabular}

${ }^{*}$ Pseudototal (aqua regia extracted) $\mathrm{Ni}$ and $\mathrm{Cu}$

${ }^{\star *}$ Reactive (0.43 $\mathrm{M} \mathrm{HNO}_{3}$ extracted) $\mathrm{Ni}$ and $\mathrm{Cu}$

Two monoliths of podzol soil and two undisturbed forest floor samples were gathered in a relatively uncontaminated area $200 \mathrm{~km}$ south-west of the smelter (Table 1). The area is covered by native spruce forest with extensive ground vegetation of bilberry, cowberry, green mosses and lichens. Another two soil columns and two forest floor samples were collected in a heavily polluted zone $7 \mathrm{~km}$ from the smelter. The soils at this point are intensively 
contaminated by acid atmospheric precipitation and airborne dust. The vegetation is represented by scarce spruce forest with patches of bare soil. Sparse ground vegetation is represented by crowberry and sometimes by grass. All plant species in this anthropogenically transformed ecosystem are suppressed by airborne pollutants.

Careful excision of soil columns with plastic tubes allowed to keep natural soil texture and density. The internal diameter of used plastic cylinders was $15 \mathrm{~cm}$. Monolith samples comprised the entire soil profile including the $B C$ horizon $(30 \mathrm{~cm})$. Forest floor samples comprised the $O$ horizon only $(10 \mathrm{~cm})$.

\subsection{Column experiment}

The samples were transported to the laboratory and set up. All the samples were regularly irrigated with solutions imitating atmospheric precipitation (Figure 1). The experiment lasted for over five months with simulated precipitation corresponding to five years of field precipitation. For both contaminated and background samples two types of precipitation were used (Table 2), so in sum four separate experiments were done: background soil and background precipitation, background soil and polluted precipitation, polluted soil and background precipitation, polluted soil and polluted precipitation. The background precipitation had a chemical composition mimicking that in nonpolluted areas of the Kola Peninsula (Lukina and Nikonov, 1996). The polluted precipitation had a composition mimicking that in the vicinity of the "Severonikel" smelter. The $\mathrm{pH}$ values of the precipitation solutions were 5.0 and 4.4, respectively. Concentrations of sulphate and heavy metals were much higher in polluted precipitation, reflecting the output of $\mathrm{SO}_{2}$, Ni and $\mathrm{Cu}$ from the smelter. Both precipitation solutions were prepared using soluble inorganic salts (nitrates, chlorides, sulphates), so all elements entered the columns in dissolved form. Irrigation was done twice a week. A special rainmaker provided irrigation intensity similar to that of natural rainfall.

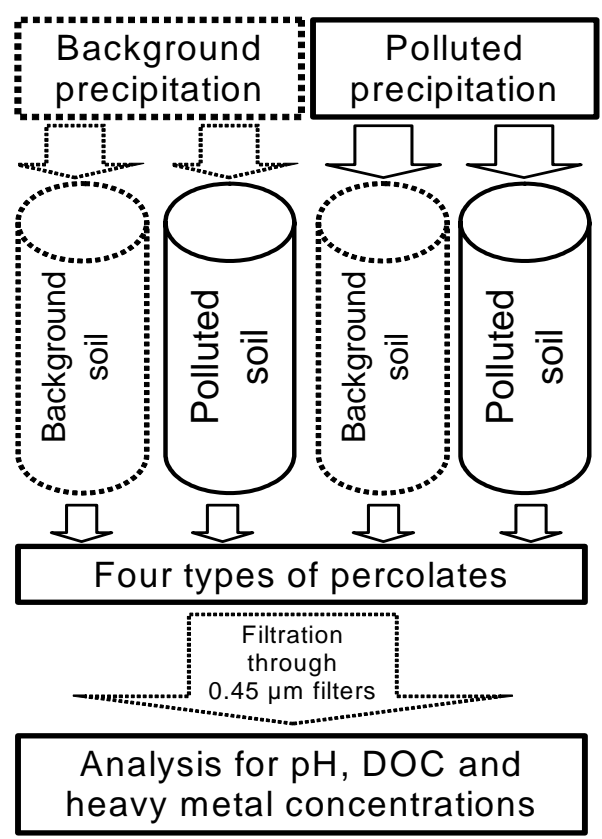

Figure 1. Scheme of column experiment

Table 2. Composition of precipitation solutions $\left(\mathrm{mg} \mathrm{l}^{-1}\right)$

\begin{tabular}{|c|c|c|c|c|c|c|c|c|c|c|}
\hline Precipitation & $\mathrm{Ca}$ & $\mathrm{Mg}$ & $\mathrm{K}$ & $\mathrm{Na}$ & $\mathrm{NH}_{4}$ & $\mathrm{Ni}$ & $\mathrm{Cu}$ & $\mathrm{SO}_{4}$ & $\mathrm{NO}_{3}$ & $\mathrm{Cl}$ \\
\hline Background & 0.55 & 0.08 & 0.24 & 0.40 & 0.61 & 0.0023 & 0.0023 & 3.5 & 0.70 & 0.63 \\
\hline Polluted & 1.20 & 0.31 & 0.37 & 0.57 & 0.95 & 0.270 & 0.310 & 9.4 & 0.72 & 0.94 \\
\hline
\end{tabular}

Percolates from column samples were collected twice a week and filtered through $0.45 \mu \mathrm{m}$ membrane filters. Concentrations of dissolved organic carbon (DOC, by Hach COD Reactor with spectrophotometer finishing), fulvic acids (by base extraction) and $\mathrm{pH}$ level (by electrode) 
were measured in the percolates. Concentrations of $\mathrm{Ni}$ and $\mathrm{Cu}$ in the percolates were analyzed by graphite atomic absorption spectrophotometry (Perkin Elmer 5000).

The results are shown in figures at log scale in order to visualize and compare the percolate concentrations which differ up to two orders of magnitude. In addition, the results were also recalculated on a g m $\mathrm{m}^{-2}$ basis to compare the DOC and metal amounts leached from the columns during the whole experimental period.

\section{RESULTS AND DISCUSSION}

\subsection{Dissolved organic carbon}

Dissolved organic carbon leached from all column samples, but the intensity of DOC leaching was quite different (Figure 2). The highest DOC concentrations were observed in percolates from background forest floor. In total, about $60 \mathrm{~g} \mathrm{DOC} \mathrm{m}^{-2}$ was leached from the background forest floor independently of precipitation type. The release of DOC from polluted forest floor was much lower and did not exceed $14 \mathrm{~g} \mathrm{DOC} \mathrm{m}^{-2}$. In case of background forest floor leaching of DOC was characterized by high initial intensity and rapid decline to constant concentrations under long-term precipitation. The intensity of DOC leaching from polluted forest floor was nearly constant. About $60-80 \%$ of DOC in background forest floor percolates was represented by fulvic acids. In leachates from contaminated forest floor samples fulvic acids represented $70-90 \%$ of total DOC.
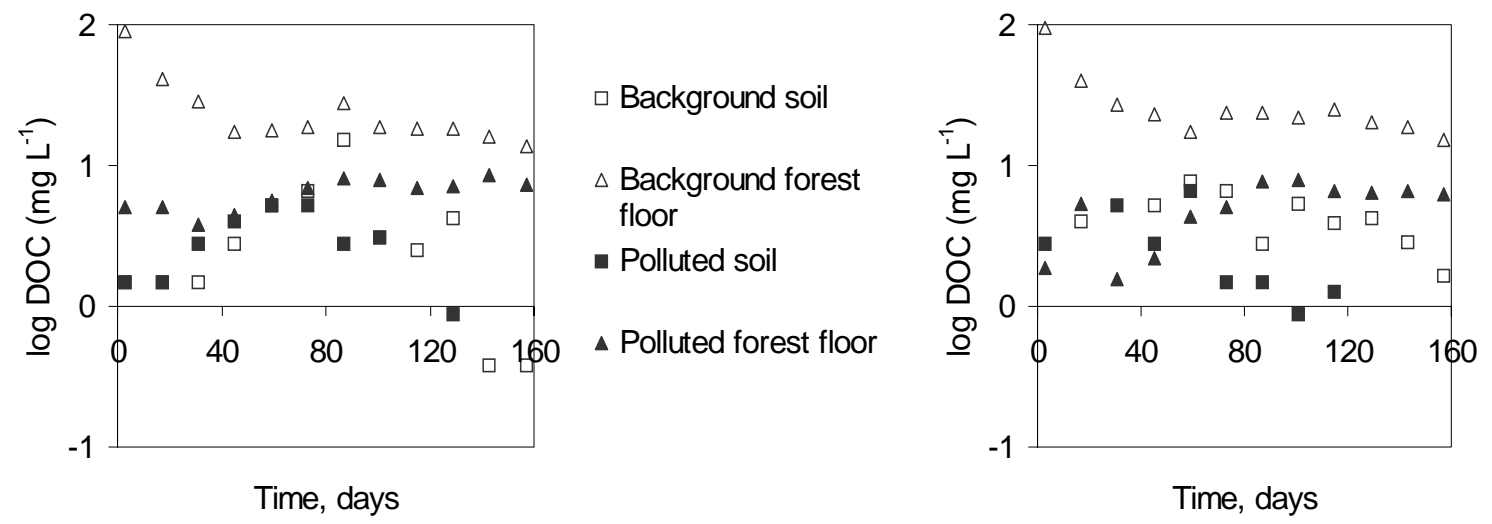

Figure 2. DOC concentrations in percolates under background (left) and polluted (right) precipitation

Significantly lower concentrations of mobile organic carbon in percolates from the polluted forest floor suggest the disruption of carbon cycling in the contaminated area. The main driver of this disruption is the deforestation caused by the toxic effects of acidity (in precipitation, and also likely from direct effects of $\mathrm{SO}_{2}$ ) and heavy metals. Ground vegetation in the unpolluted zone is well-developed and dominated by mosses and lichens which produce a great amount of organic acids. These mosses and lichens are known to be sensitive to air pollution; their disappearance is the first indicator of disruption of the ecosystem and element cycles (Koptsik et al., 2003; Lukina and Nikonov, 1996). Further effects on carbon cycling may occur due to reduced litter input resulting from tree death, increased losses of organic matter from the forest floor layer due to increased erosion resulting from the loss of vegetation, and depression of microbial decomposition under toxic metal stress (Kiikkila et al., 2002). Thus, pollution pressures tend to decrease the amount of organic matter, including potentially soluble forms, in the upper soil layer.

Profile samples consistently released less DOC than did forest floors (on a $\mathrm{g} \mathrm{m}^{-2}$ basis), indicating significant retention of DOC in mineral layers. Between 84 and $88 \%$ of DOC leached from the background forest floor was accumulated in mineral soil horizons (assuming leaching from the forest floor to be the same in both profile and floor samples), but only about $66 \%$ of leaching DOC was retained in polluted mineral samples. The reasons for differing 
retention are likely to be complex and to include variations in soil $\mathrm{pH}, \mathrm{Al}$ and $\mathrm{Fe}$ oxide contents as well as differences in organic matter composition.

\section{$3.2 \mathrm{pH}$ level}

Passage through the forest floor consistently decreased solution $\mathrm{pH}$. Irrespective of precipitation composition, $\mathrm{pH}$ in percolates from background forest floors increased from 3.6 to 4.2 over the time course of the experiment (Figure 3). Conversely, in percolates from the polluted forest floor, $\mathrm{pH}$ was constant between 3.9 and 4.0 irrespective of precipitation composition. The forest floor thus appeared to be an efficient buffer of input acidity. Increasing $\mathrm{pH}$ in percolates from the background forest floor could result from the gradual decline in DOC concentrations. The higher initial $\mathrm{pH}$ in the percolates from the polluted samples could be caused by the relatively low concentrations of DOC and base cations (Lukina and Nikonov, 1996).

Passage through the whole soil profiles consistently increased solution $\mathrm{pH}$. However, the increases were much lower when polluted precipitation was input (Figure 3), indicating the limited capacity of the mineral layers to buffer the acidity of these inputs. Acidification of soils subjected to acid deposition has been observed previously in both laboratory (Vance and David, 1991) and field (Jonsson et al., 2003) studies.
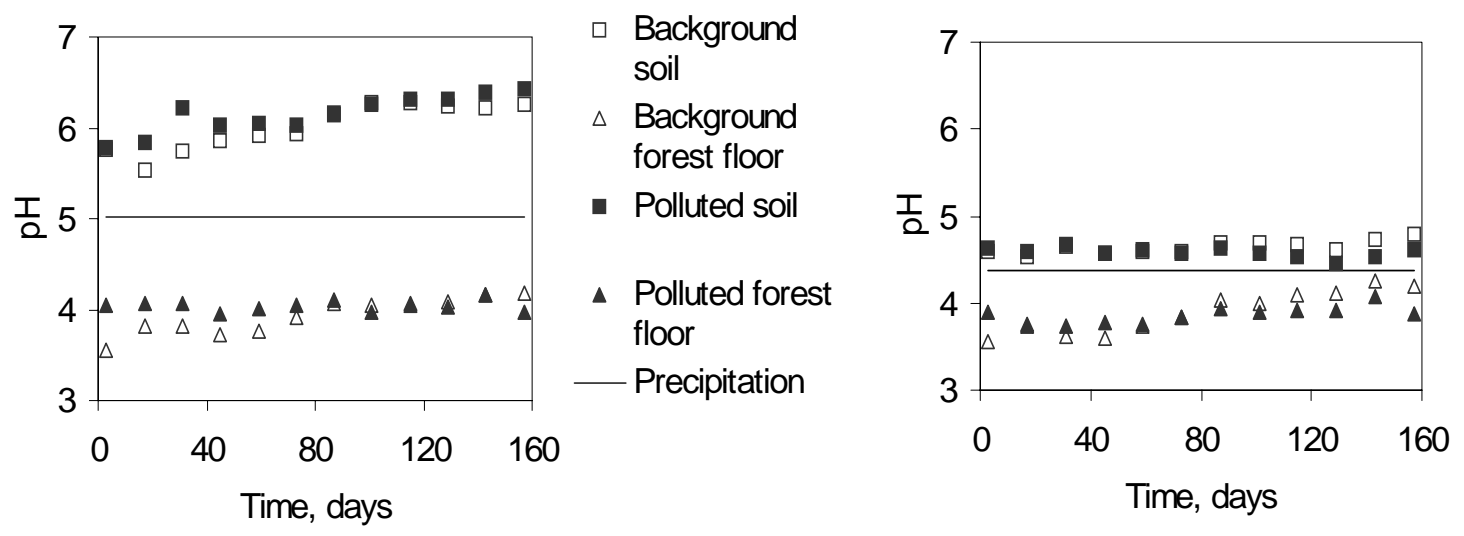

Figure 3. $\mathrm{pH}$ in percolates under background (left) and polluted (right) precipitation

Correlation analysis demonstrated a significant relationship between $\mathrm{pH}$ level and DOC concentrations in percolates from background forest floor $(r=0.61, p=95 \%)$. The $\mathrm{pH}$ of soil solutions may be influenced by concentrations of organic acids (Park et al., 2002). However, chemical speciation of percolate compositions using WHAM/Model VI (Tipping, 2002) showed that not all the variation in $\mathrm{pH}$ could be attributed to the variation in $\mathrm{DOC}$, assuming that the DOC showed a constant binding site density over time.

\subsection{Nickel}

Concentrations of $\mathrm{Ni}$ in percolates from background samples under background precipitation were very low (Figure 4). Some net retention was found but this should not be overinterpreted since the composition of the inputs may not exactly reflect the history of inputs to this soil prior to sampling.

Retention of $\mathrm{Ni}$ from the polluted precipitation by the background forest floor and whole profile was significant. Ni concentrations in percolates were at least two orders of magnitude lower than in inputs, with the exception of the forest floor where initial flushing of DOC promoted Ni leaching. Towards the end of the experiments, concentrations in percolates from the forest floor and whole profile were similar, indicating that most of the retention was occurring in the forest floor.

Under background precipitation both the polluted forest floor and profile samples were sources of $\mathrm{Ni}$, reflecting the significant accumulation of $\mathrm{Ni}$ during their pollution history. Percolate concentrations of $\mathrm{Ni}$ were $1.5-2$ orders of magnitude greater than input 
concentrations. The whole profile was a larger source than the forest floor, thus the mineral layer was itself a source. Under polluted precipitation, the polluted forest floor was a (small) sink for Ni while the whole soil profile was a source; here also the mineral layer was a source. Taken together, these results indicate that the soil would be expected to remain a significant source of $\mathrm{Ni}$ even if complete cessation of atmospheric inputs was to occur.

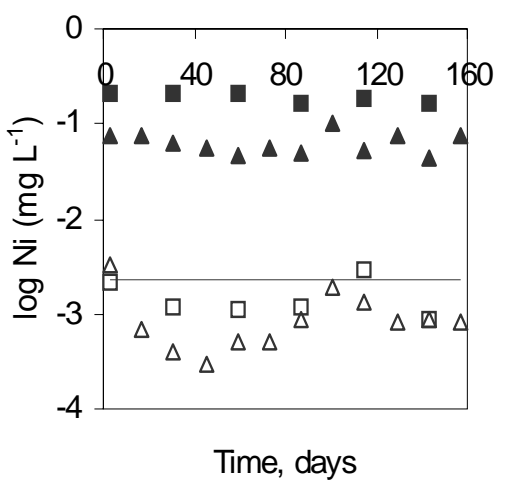

Background soil

$\triangle$ Background forest floor

- Polluted soil

- Polluted forest floor

Precipitation

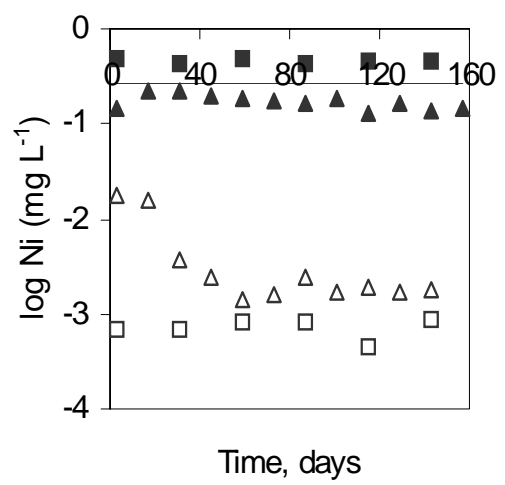

Figure 4. Ni concentrations in percolates under background (left) and polluted (right) precipitation

A strong correlation between $\mathrm{DOC}$ and $\mathrm{Ni}$ concentrations in background forest floor percolates was found under background $(r=0.77, p=95 \%)$ and polluted $(r=0.87, p=95 \%)$ precipitation, implying that $\mathrm{Ni}$ may be leached from the soil as organic complexes (Linnik and Nabivanetz, 1986). A significant correlation between concentrations of fulvic acids and $\mathrm{Ni}$ in background forest floor leachates $(r=0.80$ and 0.84 under polluted and background precipitation respectively, $p=95 \%$ ) supports the assumption that organic complexes of $\mathrm{Ni}$ are important in its leaching from the forest floor. Chemical speciation of percolate solutions using WHAM/Model VI (Tipping, 2002) also supported this; an average of about $40 \%$ of $\mathrm{Ni}$ in percolates was predicted to be organically-bound. There was however no significant correlation between DOC and Ni concentrations in polluted forest floor percolates, possibly due to the lower DOC concentrations in percolates of the polluted layers. Calculations with WHAM/Model VI indicated that organic complexation of Ni was less significant than in the background forest floor; on average $13 \%$ of Ni was predicted to be organically-bound.

\subsection{Copper}

The behaviour of $\mathrm{Cu}$ in percolates from background samples under background precipitation was very similar to the behaviour of $\mathrm{Ni}$ (Figure 5). Like $\mathrm{Ni}, \mathrm{Cu}$ in polluted precipitation was significantly retained by the background forest floor and soil profile, and also like $\mathrm{Ni}$, most of the retention appeared to take place in the forest floor. Unlike $\mathrm{Ni}$, though, $\mathrm{Cu}$ in polluted precipitation was also quite strongly retained by the polluted samples. About $90 \%$ of the input $\mathrm{Cu}$ was retained by the polluted forest floor and about $99 \%$ was retained by the whole polluted profile. Thus, both the forest floor and mineral layers remained net sinks for $\mathrm{Cu}$ despite their pollution history. Interestingly, the mineral layer appeared to be relatively more important in $\mathrm{Cu}$ retention in the polluted soil compared to the background soil. Release of $\mathrm{Cu}$ from polluted samples under background precipitation was much less intensive than the release of $\mathrm{Ni}$, though the initial concentrations of $\mathrm{Cu}$ in the samples were greater (Koptsik et al., 2003). These soils clearly have a higher retention capacity towards $\mathrm{Cu}$ compared with Ni. The mineral layers of the soil also appear to play a more significant role in retention. Intensive $\mathrm{Cu}$ retention by podzols has been observed in earlier field studies (Koptsik et al., 2003; Lukina and Nikonov, 1996; Nikonov et al., 2001). 


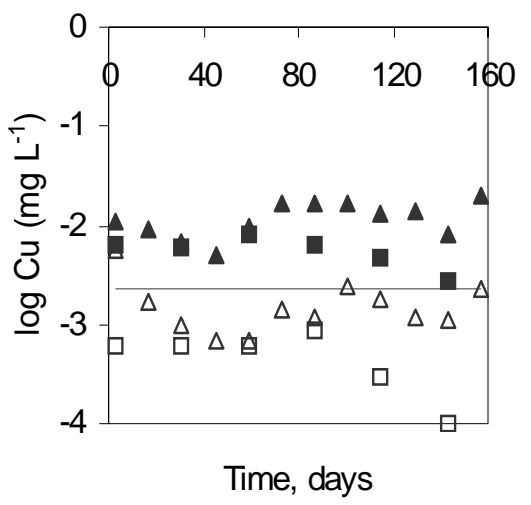

$\square \quad$ Background soil

$\Delta$ Background forest floor

- Polluted soil

- Polluted forest floor Precipitation

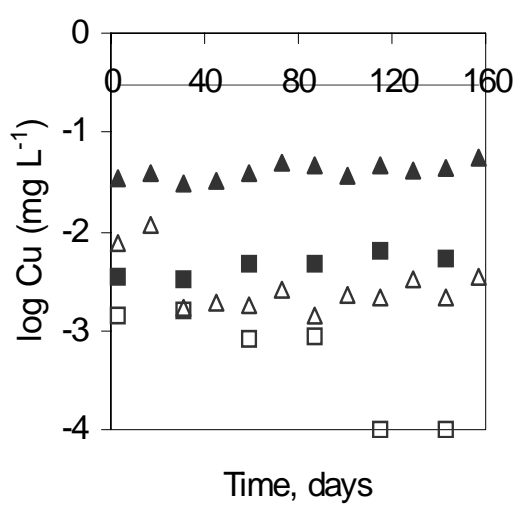

Figure 5. Cu concentrations in percolates under background (left) and polluted (right) precipitation

There was a significant relationship between concentrations of $\mathrm{Cu}$ and $\mathrm{DOC}$ in the percolates $(r=0.60-0.83, p=95 \%)$. Even better correlation was found between concentrations of $\mathrm{Cu}$ and fulvic acids ( $r=0.71-0.93, p=95 \%)$. Previous investigations (Mc-Laren et al., 1994; Nierop et al., 2002; Temminghoff et al., 1997) have shown that $\mathrm{Cu}$ may migrate as complexes with mobile organic matter. Calculations with WHAM/Model VI supported this; on average $72 \%$ and $42 \%$ of dissolved $\mathrm{Cu}$ was predicted to be organically-bound in the background and polluted forest floor percolates respectively. Although $\mathrm{pH}$ has been shown to affect $\mathrm{Cu}$ mobility in sandy soils (Temminghoff et al., 1997), no correlations between $\mathrm{pH}$ and concentration of $\mathrm{Cu}$ were found in the column percolates. The effect of $\mathrm{pH}$ is not straightforward since a higher release of metals to the soil solution due to increased proton competition as $\mathrm{pH}$ decreases could actually be partly counteracted by a concomitant decrease in complexation with dissolved ligands (Sauvé et al., 2003).

\section{CONCLUSIONS}

Although the use of soil columns in the laboratory represents a highly restricted set of conditions, we can make broad inferences regarding metal retention and leaching in podzol soils of the Kola Peninsula.

The mineral part of podzol soils was found to be very sensitive to input $\mathrm{pH}$. Contaminated precipitation with lower $\mathrm{pH}$ strongly acidified the mineral soil layers, and there is a real possibility for acidification of ground waters. The background forest floor has a very high retention capacity towards both $\mathrm{Ni}$ and $\mathrm{Cu}$. Contaminated forest floor kept almost the same buffer capacity towards $\mathrm{Cu}$ but strongly decreased the accumulation of $\mathrm{Ni}$. The retention of metals in the mineral layers was much less significant; although the polluted mineral layer removed the majority of input $\mathrm{Cu}$, it had little effect on percolate $\mathrm{Ni}$ concentrations. Thus, leaching of $\mathrm{Ni}$ from the soils is more rapid than that of $\mathrm{Cu}$, and the risk of Ni contamination of ground waters is higher. Leaching of $\mathrm{Cu}$ would be expected to take place over a longer time period than for $\mathrm{Ni}$, giving a consequently lower risk of groundwater pollution, although over a longer time period. As well as reductions in current smelter emissions, risk reduction and ecosystem restoration in the affected areas of the Kola Peninsula are likely to benefit from remediation of current pollution levels in the soils.

\section{ACKNOWLEGEMENTS}

The work was supported by INTAS (01-2213), EC FP6 (INCO-CT-2005-013420) and RFBR (05-04-48460).

\section{REFERENCES}

Camobreco V.J., Richards B.K., Steenhuis T.S., Peverly J.H. and Mc-Bride M.B., (1996) Movement of heavy metals through undisturbed and homogenized soil columns, Soil Science, 161(11), 740-750. 
Derome J. and Lindroos A.-J., (1998) Effects of heavy metal contamination on macronutrient availability and acidification parameters in forest soil in the vicinity of the Harjavalta Cu-Ni smelter, SW Finland, Environmental Pollution, 99(2), 225-232.

Jonsson U., Rosengren U., Thelin G. and Nihlgard B., (2003) Acidification-induced chemical changes in coniferous forest soils in southern Sweden 1988-1999, Environmental Pollution, 123, 75-83.

Kiikkila O., Derome J., Brugger T., Uhlig C. and Fritze H., (2002) Copper mobility and toxicity of soil percolation water to bacteria in a metal polluted forest soil, Plant and Soil, 238(2), 273280.

Koptsik G.N., Niedbaiev N.P., Koptsik S.V. and Pavlyuk I.N., (1998) Heavy metal pollution of forest soils by atmospheric emissions of Pechenganikel smelter, Eurasian Soil Science, 31(8), 896-903.

Koptsik S. and Koptsik G., (2001) Effects of acid deposition on forest ecosystems in northernmost Russia: modelled and field data, Water, Air and Soil Pollution, 130, 1277-1282.

Koptsik S., Koptsik G., Livantsova S., Eruslankina L., Zhmelkova T. and Vologdina Zh., (2003) Heavy metals in soils near the nickel smelter: chemistry, spatial variation, and impacts on plant diversity, Journal of Environmental Monitoring, 5, 441- 450.

Linnik P.N. and Nabivanetz B.I., (1986) Forms of heavy metal migration in fresh surface waters, Hydrometeorology, Leningrad (In Russian).

Lukina N.V. and Nikonov V.V., (1996) Biogeochemical Cycles in the Northern Forests Subjected to Air Pollution, Kola Science Centre, Russian Academy of Science, Apatity, Parts 1, 2 (In Russian).

Mc-Laren R.G., Carey P.L., Cameron K.C., Adams J.A. and Sedcole J.R., (1994) Effect of soil properties and contact period on the leaching of copper, chromium and arsenic through undisturbed soils, 15th World Congress of Soil Science, Acapulco, 3a, 156-169.

Nierop K.G.J., Jansen B., Vrugt J.A. and Verstraten J.M., (2002) Copper complexation by dissolved organic matter and uncertainly assessment of their stability constants, Chemosphere, 49, 1191-1200.

Nikonov V., Goryainova V. and Lukina N., (2001) Ni and Cu migration and accumulation in forest ecosystems on the Kola Peninsula, Chemosphere, 42, 93-100.

Park J.-H., Kalbitz K. and Matzner E. (2002) Resource control on the production of dissolved organic carbon and nitrogen in a deciduous forest floor, Soil Biology \& Biochemistry, 34, 813-822.

Sauvé S., Manna S., Turmel M.-C., Roy A.G. and Courchesne F., (2003) Solid-Solution Partitioning of $\mathrm{Cd}, \mathrm{Cu}, \mathrm{Ni}, \mathrm{Pb}$, and $\mathrm{Zn}$ in the Organic Horizons of a Forest Soil, Environ. Sci. Technol., 37, 5191-5196.

Temminghoff E.J.M., Van-Der-Zee S.E.A.T.M. and De-Haan F.A.M., (1997) Copper mobility in a copper-contaminated sandy soil as affected by $\mathrm{pH}$ and solid and dissolved organic matter, Environ. Sci. Technol., 31, 1109-1115.

Tipping E. (2002) Cation binding by humic substances, Cambridge University Press, Cambridge.

Vance G.F. and David M.B., (1991) Forest soil response to acid and salt additions of sulfate: III. Solubilization and composition of dissolved organic carbon, Soil Science, 151, 297-305. 